\title{
Effect of Polymer Coat and Seed Treatment Chemicals on Field Performance of Chickpea
}

\author{
P.P. Sushma*, S. B. Vinodkumar, K.S. Siddarudh, \\ B.S. Vyakaranahal and Vinod Kumar
}
Department of Seed Science Technology, University of Agricultural sciences, Bangalore-65, Karnataka, India

*Corresponding author

\section{A B S T R A C T}

The experiment was laid on Randomised Complete Block Desighn with factorial concept in three replications to know the effect of polymer coat and seed treatment chemicals on

Keywords

Chickpea, Seed treatment, Polymer coat, Field performance

\section{Article Info}

\section{Accepted:}

16 March 2018

Available Online:

10 April 2018 field performance of chickpea verities. Desi and kabuli type of chickpea varieties were used for seed treatment. The treatment combinations as follows $\mathrm{T}_{1}$ : control (Untreated), $\mathrm{T}_{2}$ : deltamethrin 2.8EC @ $0.4 \mathrm{ml} / \mathrm{kg}$ seeds. $\mathrm{T}_{3}$ : vitavax power @ $2 \mathrm{~g} / \mathrm{kg}$ seed, $\mathrm{T}_{4}$ : polymer coat@10ml $/ \mathrm{kg}$ of seeds, $\mathrm{T}_{5}$ : deltamethrin 2.8EC @ $0.4 \mathrm{ml} / \mathrm{kg}$ seeds + vitavax power @ $2 \mathrm{~g} / \mathrm{kg}$ seed, $\mathrm{T}_{6}$ : deltamethrin $2.8 \mathrm{EC} @ 0.4 \mathrm{ml} / \mathrm{kg}$ seeds + polymer coat @ $10 \mathrm{ml} / \mathrm{kg}$ of seeds, $\mathrm{T}_{7}$ : Vitavax power @ $2 \mathrm{~g} / \mathrm{kg}$ seed+ polymer coat @ $10 \mathrm{ml} / \mathrm{kg}$ of seed, $\mathrm{T}_{8}$ : Deltamethrin $2.8 \mathrm{EC} @ 0.4 \mathrm{ml} / \mathrm{kg}$ seeds + vitavax power@2g/kg seed+ polymer coat @ 10ml $/ \mathrm{kg}$ of seeds. The results revealed that superior plant height, number of branches, number of pods per plant, number of seeds per plant, seed weight per plant, seed weight per plot, seed yield per hectare was recorded at harvest stage. Observations on seed quality parameter like seed germination $(\%)$, shoot length $(\mathrm{cm})$, root length $(\mathrm{cm})$, seedling vigour, seedling dry weight $(\mathrm{mg})$, hundred seed weight $(\mathrm{g})$ was recorded in the treatment combination of Deltamethrin 2.8EC @ $0.4 \mathrm{ml} / \mathrm{kg}$ seeds + vitavax power @ 2g/kg seed+ polymer coat @ $10 \mathrm{ml} / \mathrm{kg}\left(\mathrm{T}_{8)}\right.$.

\section{Introduction}

Chickpea is one of the earliest food legumes cultivated by man and plays an important role in human diet and agricultural systems. Chickpea belongs to the genus Cicer and family Fabaceae. Chickpea is the second most widely grown legume crop of the world after soybean. During 2011-2012, the global chickpea area was about 13.20 million ha, with production of 11.62 million metric tons and average yield of $804 \mathrm{~kg}^{-} \mathrm{ha}^{-}$. India is the largest chickpea producing country with a share of about $68 \%$ in the global chickpea production. In India estimated area, production and productivity during 2013-14 was $10.74 \mathrm{mha}, 9.88 \mathrm{~m}$ tonnes and $9199 \mathrm{~kg}$ $\mathrm{ha}^{-1}$ respectively (FAOSTAT, 2014). Among the cultivated species, Desi and Kabuli types are of practical importance, which covers 85 and 15 per cent of total cultivated area, respectively. Desi types are small seeded, varied coloured with thick seed coat and 
reticulated surface. The flower colour is purple or pink with anthocyanin pigment in aerial parts and the protein content is around18 to 19 per cent. Whereas in Kabuli type seeds are large, whitish with thin testa and smooth surface. Flowers are white, without anthocyanin pigment in aerial parts and the protein content is around is 20 to 23 per cent.

High seed emergence and seedling establishment contribute directly to the crop yield (Vinodkumar, et al., 2012). Therefore Seed viability is a major factor in crop stand establishment and subsequent productivity in many parts of the world. Losses in seed quality occur during field weathering, harvesting and storage due to which seeds get damaged. If seeds are exposed to high temperature and high humidity, the incidence of micro flora is mainly responsible for the degradation of protein and other food reserves resulting in reduction in viability, vigour and germination. Seed is an efficient media for survival and dissemination of pathogens and pests to reduce the losses and preserve the viability for longer time, it is advisable to coat the seeds with polymer, fungicide and insecticide. Seed coating provides an opportunity to package effective quantities of seed treatment chemicals keeping this in the view an experiment was conducted to know the effect of polymer coat and seed treatment chemicals on field performance of Chickpea.

\section{Materials and Methods}

The experiment was laid on RCBD factorial concept in three replications the first factor consists of varieties and second factor is treatments. The treatment combinations as follows $\mathrm{T}_{1}$ : control (Untreated), $\mathrm{T}_{2}$ : deltamethrin 2.8EC @ $0.4 \mathrm{ml} / \mathrm{kg}$ seeds. $\mathrm{T}_{3}$ : vitavax power @2g/kg seed, $\mathrm{T}_{4}$ : polymer coat $@ 10 \mathrm{ml} / \mathrm{kg}$ of seeds, $\mathrm{T}_{5}$ : deltamethrin 2.8EC@0.4ml / kg seeds + vitavax power @ 2g/kg seed, $\mathrm{T}_{6}$ : deltamethrin 2.8EC @ $0.4 \mathrm{ml}$ $/ \mathrm{kg}$ seeds + polymer coat @ $10 \mathrm{ml} / \mathrm{kg}$ of seeds, $\mathrm{T}_{7}$ : Vitavax power@2g/kg seed+ polymer coat @10 ml $/ \mathrm{kg}$ of seed, $\mathrm{T}_{8}$ : Deltamethrin $2.8 \mathrm{EC} @ 0.4 \mathrm{ml} / \mathrm{kg}$ seeds + vitavax power @ $2 \mathrm{~g} / \mathrm{kg}$ seed+ polymer coat @ 10ml $/ \mathrm{kg}$ of seeds. Two varieties of chickpea viz., BGD103 (desi type) and BG1105 (Kabuli type) was obtained from seed unit and MULLARP scheme respectively, University of agricultural sciences, Dharwad. The observations on plant height, number of branches, number of pods per plant, number of seeds per plant, seed weight per plant, seed weight per plot, seed yield per hectare was recorded at harvest stage. Observations on seed quality parameter like seed germination $(\%)$, shoot length $(\mathrm{cm})$, root length $(\mathrm{cm})$, seedling vigour, seedling dry weight $(\mathrm{mg})$, hundred seed weight $(\mathrm{g})$ was recorded. The data was statistically analysed and results are presented in table 1,2 and 3.

\section{Results and Discussion}

In the present investigation, varietal differences with respect to field performance have been noticed in chickpea varieties. Significant variation in the growth parameter at the harvest was observed in chickpea varieties irrespective of treatments. Significantly BGD 103 recorded lesser plant height $(41.39 \mathrm{~cm})$, less number of days to 50 per cent flowering and days to maturity (46.29 and 92.91). This may be mainly due to efficient accumulation of photosynthates in the vegetative plant parts. Besides the plant height is also a genetic character of varieties. The varietal difference in growth parameter in chickpea was also observed by Gnyandev (2009). BGD 103 recorded higher number of branches (19.25), number of pods per plant (28.90), number of seed per plant (35.46), seed weight per plant $(4.33 \mathrm{~g})$, seed weight per plot $(1.30 \mathrm{~kg})$, and seed yield per hectare (14.42 q) as compared to BG1105 (48.77 and 
$103.16,25.85,32.713 .46 \mathrm{~g}, 1.04 \mathrm{~kg}$ and $11.58 \mathrm{q}$ respectively). The differences on seed yield and yield components were observed between varieties in the present study may be attributed to their varietal differences in their growth habit and genetic yielding ability.

Similar varietal difference in chickpea with respect to plant growth, seed yield and yield attributes by Merwade (2000) in chickpea and in cowpea by Reddy (2005), Gnyandev (2009) and Tripathi et al., (2012). It is an established fact that seed yield and quality attributes are reported to vary between the varieties of several crop species owing to genetic and environmental factors. In the present investigation, all the seed quality parameters were found to differ between chickpea varieties.

The hundred seed weight (34.12 g), germination (95.46\%), shoot length (12.48 $\mathrm{cm})$, root length $(20.87 \mathrm{~cm})$, dry weight $(207.18 \mathrm{mg}$ ), vigour index (3185) were more and low electrical conductivity $\left(0.343 \mathrm{dSm}^{-1}\right)$ in BGD103 $\left(\mathrm{V}_{1}\right)$ as compared to BG1105 $\left(\mathrm{V}_{2}\right)$ (Table 3 and 4). The differences in seed quality attributes were noticed between chickpea varieties it may be ascertained due to the varietal differences in seed development and accumulation of reserved food material. The similar results were reported by Gnyandev (2009) in chickpea.

Table.1 Effect of polymer coat and seed treatment chemicals on plant height $(\mathrm{cm})$, number of branches per plant and number of pods per plant in chickpea

\begin{tabular}{|c|c|c|c|c|c|c|c|c|c|}
\hline \multirow[t]{2}{*}{ Treatments } & \multicolumn{3}{|c|}{ Plant height(cm) } & \multicolumn{3}{|c|}{ Number of branches/plant } & \multicolumn{3}{|c|}{ Number of pods per plant } \\
\hline & $\mathbf{V}_{1}$ & $\mathbf{V}_{2}$ & Mean & $\mathbf{V}_{1}$ & $\mathbf{V}_{2}$ & Mean & $V_{1}$ & $\mathbf{V}_{2}$ & Mean \\
\hline$T_{1}$ & 39.48 & 43.82 & 41.65 & 16.80 & 13.18 & 14.99 & 24.51 & 21.80 & 23.15 \\
\hline $\mathbf{T}_{2}$ & 39.91 & 44.04 & 41.97 & 17.19 & 14.74 & 15.97 & 25.87 & 23.63 & 24.75 \\
\hline $\mathbf{T}_{3}$ & 42.03 & 45.98 & 44.00 & 19.40 & 17.19 & 18.29 & 28.93 & 25.87 & 27.40 \\
\hline$\overline{T_{4}}$ & 40.26 & 44.32 & 42.29 & 18.07 & 15.18 & 16.62 & 27.03 & 24.65 & 25.84 \\
\hline$T_{5}$ & 42.31 & 46.04 & 44.17 & 20.00 & 17.73 & 18.87 & 30.76 & 26.27 & 28.51 \\
\hline$\overline{T_{6}}$ & 40.88 & 44.98 & 42.93 & 18.67 & 16.03 & 17.35 & 28.32 & 24.85 & 26.59 \\
\hline $\mathrm{T}_{7}$ & 43.13 & 46.21 & 44.67 & 21.55 & 19.03 & 20.29 & 32.72 & 28.93 & 30.82 \\
\hline$\overline{T_{8}}$ & 43.17 & 46.26 & 44.71 & 22.33 & 20.27 & 21.30 & 33.05 & 30.76 & 31.91 \\
\hline \multirow[t]{2}{*}{ Mean } & 41.39 & 45.21 & 43.30 & 19.25 & 16.67 & 17.96 & 28.90 & 25.85 & 27.37 \\
\hline & \multicolumn{2}{|c|}{ S Em \pm} & $\mathrm{D}(\mathrm{P}=0.05)$ & $\mathbf{S E}$ & & $(P=0.05)$ & S EI & & $(P=0.05)$ \\
\hline $\mathbf{V}$ & 0.8 & & 2.36 & 0. & & 1.44 & 0.6 & & 1.84 \\
\hline $\mathbf{T}$ & 1.6 & & NS & 0. & & 2.87 & 1.2 & & 3.68 \\
\hline VXT & 2.3 & & NS & 1. & & NS & 1.8 & & NS \\
\hline $\mathrm{V}_{1}$-BGD $103(L$ & & & $\mathrm{V}_{2}-\mathrm{BG} 110$ & 5 (Kabul & & & & & \\
\hline NS - Non signil & cant & & * Figures in & the pare & hesis a & Ircsine tr: & ormed v & & \\
\hline$T_{1}-$ Control & & & & $\begin{array}{l}\mathrm{T}_{5} \text {-De } \\
\text { power }\end{array}$ & $\begin{array}{l}\text { methrin } \\
2 \mathrm{~g} / \mathrm{kg} \mathrm{o}\end{array}$ & $\begin{array}{l}2.8 \text { EC } 0 . \\
\text { eds. }\end{array}$ & per kg & seeds & \\
\hline $\mathrm{T}_{2}$ - Deltamethı & $2.8 \mathrm{EC}$ & @ 0.4 & $\mathrm{I} / \mathrm{kg}$ of seeds. & $\begin{array}{l}\mathrm{T}_{6}-\mathrm{D} \\
@ 10 \mathrm{r}\end{array}$ & $\begin{array}{l}\text { Imethrin } \\
\mathrm{kg} \text { of se }\end{array}$ & $2.8 \mathrm{EC} 0.4$ & $\mathrm{l} / \mathrm{kg}$ of & + po & coat \\
\hline$T_{3^{-}}$Vitavax po & er@2g/ & g of seer & & $\begin{array}{l}\mathrm{T}_{7^{-}} \mathrm{V} \\
\text { of see }\end{array}$ & ax pow & @ $2 \mathrm{~g} / \mathrm{kg}$ of & seeds $+p$ & mer co & $10 \mathrm{ml} / \mathrm{kg}$ \\
\hline $\mathrm{T}_{4^{-}}$Polymer & @10 & Ing & & $\begin{array}{l}\mathrm{T}_{8}-\mathrm{D} \\
\text { power }\end{array}$ & 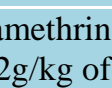 & $\begin{array}{l}.8 \mathrm{EC} \text { per } \\
\mathrm{ds}+\text { poly }\end{array}$ & $f$ & . & us. \\
\hline
\end{tabular}


Table.2 Effect of polymer coat and seed treatment chemicals on number of seeds per plant, seed weight/plant, seed weight/pot and seed yield in chickpea

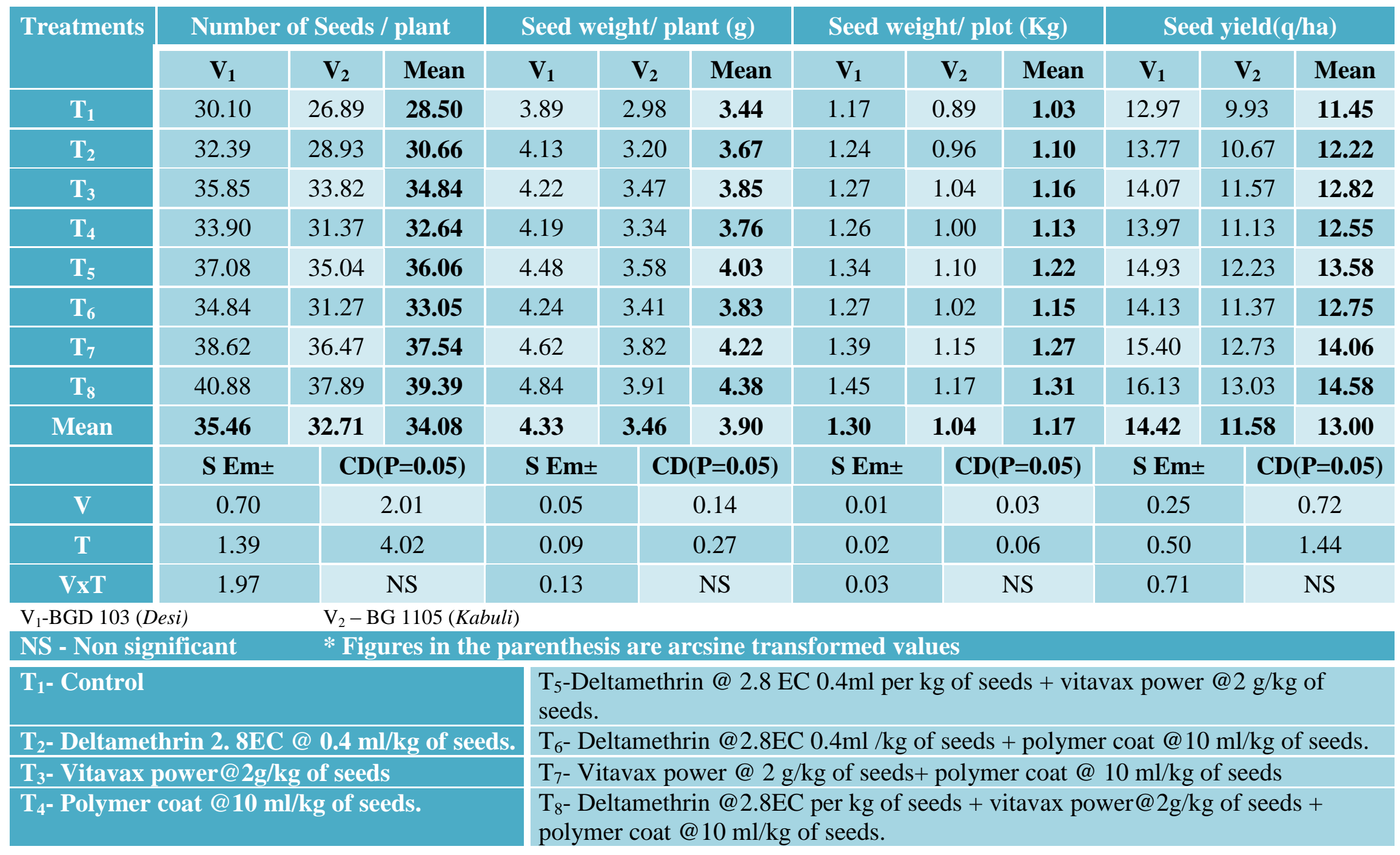


Table.3 Effect of polymer coat and seed treatment chemical on germination $(\%)$, shoot length $(\mathrm{cm})$ and root length (cm) in chickpea

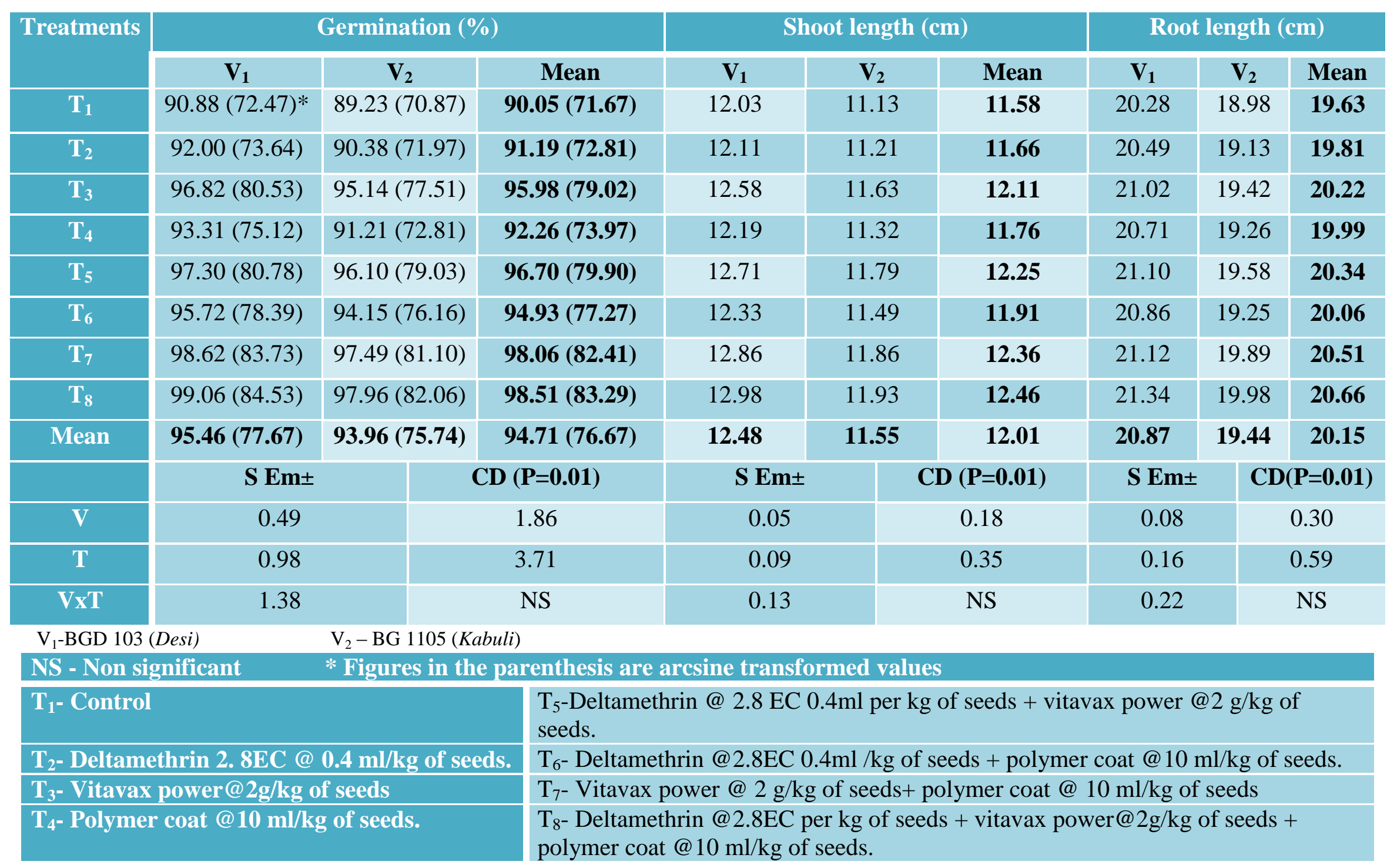


Table.4 Effect of polymer coat and seed treatment chemical on vigour index, dry weight (mg), test weight (g) and electrical conductivity $\left(\mathrm{dSm}^{1}\right)$ in chickpea

\begin{tabular}{|c|c|c|c|c|c|c|c|c|c|c|c|c|c|}
\hline \multirow[t]{2}{*}{ Treatments } & \multicolumn{3}{|c|}{ Vigour Index } & \multicolumn{4}{|c|}{ Dry weight(G) } & \multicolumn{3}{|c|}{ Test weight(g) } & \multicolumn{3}{|c|}{ Electrical conductivity } \\
\hline & $V_{1}$ & $\mathbf{V}_{2}$ & Mean & $V_{1}$ & \multicolumn{2}{|c|}{$\mathbf{V}_{2}$} & Mean & $V_{1}$ & $\mathbf{V}_{2}$ & Mean & $V_{1}$ & $\mathbf{V}_{2}$ & Mean \\
\hline$T_{1}$ & 2937 & 2687 & 2812 & 189.60 & \multicolumn{2}{|c|}{175.47} & 182.53 & 33.61 & 29.13 & 31.37 & 0.369 & 0.379 & 0.374 \\
\hline $\mathbf{T}_{2}$ & 3000 & 2743 & 2871 & 192.32 & \multicolumn{2}{|c|}{182.23} & 187.27 & 33.79 & 29.28 & 31.54 & 0.365 & 0.371 & 0.368 \\
\hline $\mathbf{T}_{3}$ & 3254 & 2955 & 3104 & $205.8 \varepsilon$ & \multicolumn{2}{|c|}{201.63} & 203.76 & 34.21 & 29.83 & 32.02 & 0.338 & 0.345 & 0.342 \\
\hline $\mathbf{T}_{4}$ & 3071 & 2790 & 2930 & 195.40 & \multicolumn{2}{|c|}{189.48} & 192.44 & 33.87 & 29.42 & 31.65 & 0.354 & 0.362 & 0.358 \\
\hline $\mathbf{T}_{5}$ & 3290 & 3015 & 3153 & 216.82 & \multicolumn{2}{|c|}{210.15} & 213.49 & 34.38 & 30.09 & 32.24 & 0.331 & 0.338 & 0.335 \\
\hline $\mathrm{T}_{6}$ & 3178 & 2895 & 3036 & 198.73 & \multicolumn{2}{|c|}{194.81} & 196.77 & 33.98 & 29.69 & 31.84 & 0.343 & 0.352 & 0.348 \\
\hline $\mathrm{T}_{7}$ & 3352 & 3096 & 3224 & 228.47 & & .54 & 223.51 & 34.51 & 30.42 & 32.47 & 0.325 & 0.332 & 0.329 \\
\hline $\mathrm{T}_{8}$ & 3401 & 3127 & 3264 & 230.17 & & .43 & 226.30 & 34.59 & 30.51 & 32.55 & 0.319 & 0.328 & 0.324 \\
\hline Mean & 3185 & 2913 & 3049 & 207.18 & & & 203.26 & 34.12 & 29.80 & 31.96 & 0.343 & 0.351 & 0.347 \\
\hline & S En & & $(\mathrm{P}=0.01)$ & $\mathbf{S} \mathbf{E}$ & & $\mathrm{CD}$ & $(P=0.01)$ & S Em & CD & $(P=0.01)$ & S En & & $\mathrm{CD}(\mathrm{P}=0.01)$ \\
\hline $\mathbf{V}$ & 12 & & 45 & 0. & & & 2.99 & 0.12 & & 0.47 & 0.00 & & 0.004 \\
\hline $\mathbf{T}$ & 24 & & 90 & 1. & & & 5.99 & 0.25 & & 0.94 & 0.00 & & 0.010 \\
\hline VxT & 33 & & NS & 2. & & & NS & 0.35 & & NS & 0.00 & & NS \\
\hline $\mathrm{V}_{1}$-BGD $103(D$ & & & BG 1105 ( & & & & & & & & & & \\
\hline NS - Non sig & ificant & & gures in & e par & nthe & - & arcsine $t$ & insform & d valu & & & & \\
\hline $\mathrm{T}_{1}$ - Control & & & & & eeds & & hrin@2. & $\mathrm{EC} 0.4 \mathrm{~m}$ & per kg & seeds & avax & r @2 & /kg of \\
\hline $\mathrm{T}_{2-}$-Deltamet & $\operatorname{rin} 2.8$ & $\bar{c} @ 0$ & $\mathrm{ml} / \mathrm{kg}$ of & eeds. & $\Gamma_{6}-\mathrm{D}$ & tame & thrin@2.8 & $\mathrm{EC} 0.4 \mathrm{~m}$ & $/ \mathrm{kg}$ of $\mathrm{s}$ & eeds + pol & ner coat & $10 \mathrm{ml} /$ & $\mathrm{kg}$ of seeds. \\
\hline $\mathrm{T}_{3^{-}}$Vitavax & ower@ & kg of & & & $\Gamma_{7-} V$ & avax & power@2 & $\mathrm{g} / \mathrm{kg}$ of & eeds +1 & olymer c & @ $10 \mathrm{r}$ & $\mathrm{g}$ of se & eds \\
\hline $\mathbf{T}_{4}$ - Polymer & oat @1 & $\mathrm{nl} / \mathrm{kg}$ & seeds. & & 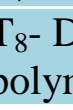 & 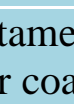 & $\begin{array}{l}\text { thrin @2.8 } \\
\mathrm{t} @ 10 \mathrm{ml} / \mathrm{t}\end{array}$ & $\mathrm{EC}$ per 1 & of see & + vitav & power & $/ \mathrm{kg}$ of & seeds + \\
\hline
\end{tabular}


Among the treatments, $\mathrm{T}_{8}$ (deltamethrin $2.8 \mathrm{EC} 0.4 \mathrm{ml} / \mathrm{kg}$ seeds + vitavax power @2 $\mathrm{g} / \mathrm{kg}$ seed + polymer coat @ $10 \mathrm{ml} / \mathrm{kg}$ of seeds) recorded significantly higher number of branches (21.30), number of pods per plant (31.91), number of seeds per plant (39.39), seed weight per plant $(4.38 \mathrm{~g})$, seed weight per plot $(1.31 \mathrm{~kg})$, seed yield per ha $(14.58 \mathrm{q})$ and followed by $\mathrm{T}_{7}$ (vitavax power @ $2 \mathrm{~g} / \mathrm{kg}$ seed + polymer coat @ $10 \mathrm{ml} / \mathrm{kg}$ of seeds) $(44.67 \mathrm{~cm}, 20.29,30.82,37.54,4.22 \mathrm{~g}, 1.27 \mathrm{~kg}$, 14.06q).An increase in plant height in $\mathrm{T}_{8}$ and $\mathrm{T}_{7}$ may be due to Polymer coating acts as a temperature switch and protective coating by regulating the seed coating uptake of water, until the soil has warmed to a predetermined temperature (Vinodkumar et al., 2012). It enables accurate and even doses of chemicals and reduces the chemical wastage; it also makes room for including all the required ingredients like inoculants, protectants, nutrients, herbicides, oxygen suppliers etc. It also provides resistance against mechanical damage in the seed drill. Thus improves the appearance and quality of polymer coated seeds (Vanangamudi et al., 2003). As the seed treatments with fungicide and insecticide help in the protection of seed from the seed rot and seedling diseases. Seed treatments by its protective coating around the seed, acts as a barrier once the seed is been planted to ward off attack of seed borne diseases and soil borne organisms by this way it enhances the better field stand. Chikkanna et al., (2000) in his experiment in groundnut seeds coated with polymer @ $20.00 \mathrm{~g}$ per kg of seeds recorded higher dry matter, number of pods, test weight and pod yield per plant and per ha and Vinodkumar et al., (2012) in Pigeonpea.

The results of seed quality parameters due to seed treatments showed significant difference. $\mathrm{T}_{8}$ (deltamethrin 2.8EC $0.4 \mathrm{ml} / \mathrm{kg}$ seeds + vitavax power @ $2 \mathrm{~g} / \mathrm{kg}$ seed + polymer coat @ $10 \mathrm{ml} / \mathrm{kg}$ of seeds), recorded the higher vigour index (3264) over all other treatments and the lowest values (2812) was with $\mathrm{T}_{1}$ (control). These results are in agreement with the findings of Vanangamudi et al., (2003) who have noticed higher germination (98.00 $\%)$ compared to control $(93.00 \%)$ in maize coated with pink polykote @ $3 \mathrm{~g} \mathrm{~kg}$-1 of seed + fungicide + insecticide treatment. Similar trend was noticed with 100 seed weight $(32.55 \mathrm{~g})$ germination percentage (98.51) root length $(20.66 \mathrm{~cm})$, shoot length $(12.46 \mathrm{~cm})$ and seedling dry weight of $(226.30 \mathrm{mg})$ as compared to the $\mathrm{T}_{1}$ (control). These findings were similar with Vinodkumar et al., (2012) in pigeonpea. In conclusion BGD 103 is early maturing variety and superior yield and seed quality than the BG1105. Seeds treated with deltamethrin 2.8EC $0.4 \mathrm{ml} / \mathrm{kg}$ seeds + vitavax power@2 g/kg seed + polymer coat @ $10 \mathrm{ml} / \mathrm{kg}$ of seeds was good in crop growth, yield and seed quality than untreated seeds of chickpea.

\section{References}

Gnyandev, B., Seed technological studies in chickpea varieties (Cicer arietinum L.) Ph.D. Thesis. Univ. Agril. Sci., Dharwad, Karnataka, India.

Merwade, M. N., 2000, Investigation on seed production techniques and storability of chickpea. M.Sc. (Agri.) Thesis, Uni. Agril. Sci., Dharwad, Karnataka (India).

Reddy, P., 2005, Effect of growth retardants and nipping on growth and yield parameters in cowpea (Vigna unguicalata L.). M.Sc. (Agri) Thesis, Univ. Agril. Sci., Dharwad, Karnataka (India).

Tripathi, S., Sridhar, V., Aravind K. Jukanti, Suresh, K., Rao, B.V., Gowda, C.L.L. and Gaur, M. P., (2012) Genetic variability and inter-relationships of phenological, physicochemical and cooking quality traits in chickpea. Intnat. Crops Res. Institute for the SemiArid Tropics (ICRISAT), Patancheru. 
Vanangamudi, K., Srimathi, P., Natarajan, N. and Bhaskaran, M., 2003, Current scenario of seed coating polymer. ICAR - Short Course on Seed Hardening and Pelleting Technologies for Rain Fed or Garden Land Ecosystems, pp: 80-100.

Vinodkumar, S. B., Vyakaranahal, B. S., Dhananjaya, P., Yegappa Hipparagi.,
Asha, A. M., 2012, Effect of seed polymer coating on field performance and quality of Pigeonpea [Cajanus cajan (L.) Millsp]. Eng. \& Ecology, 31 (1): 43-46. www.faostat.org.

\section{How to cite this article:}

Sushma, P.P., S.B. Vinodkumar, K.S. Siddarudh, B.S. Vyakaranahal and Vinod Kumar. 2018. Effect of Polymer Coat and Seed Treatment Chemicals on Field Performance of Chickpea. Int.J.Curr.Microbiol.App.Sci. 7(04): 2026-2033. doi: https://doi.org/10.20546/ijcmas.2018.704.233 